\title{
Identification of heavy metal pollution source due to idol immersion activity across the Cauvery river basin, Tamil Nadu, South India
}

\author{
Vinothkannan Anbazhagan, Rajaram Rajendran*, Ganeshkumar Arumugam \\ and Arun Ganeshan \\ DNA Barcoding and Marine Genomic Laboratory, Department of Marine Science, Bharathidasan University, Tiruchirappalli 620 024, India
}

\begin{abstract}
Idol immersion activities alter the hydrological parameters of an aquatic body. However, relevant research in the Cauvery river basin in terms of idol immersion activity has been limited. In the present study, a total of 29 water and topsoil samples were collected from the Cauvery basin before and after idol immersion, and evaluated for the presence of metals. The experimental results showed elevated $\mathrm{Cd}$ and $\mathrm{Pb}$ levels in water and sediment samples of both Cauvery and Kollidam rivers. Strong statistical significance was observed for all the elements studied in the soil samples collected before and after idol immersion $(P<0.01)$. Industrial effluents, textile waste, untreated sewage, municipal waste and agricultural activities are the most common causes of elevated levels of heavy metals in the study area. Further, geo-accumulation index and pollution load index studies showed lesser impact of idol immersion on metal distribution compared to other sites reported from India. However, strict regulatory policies of the concerned authorities help maintain the quality of the Cauvery basin.
\end{abstract}

Keywords: Geo-accumulation index, heavy metals, idol immersion, pollution load index, river basin.

WATER plays a vital role in the survival of life on Earth. Several sources fulfil the requirement of water like rainwater, rivers, lakes, ponds, etc. Among them, the river ecosystem is considered as essential as it serves many purposes like irrigation, increasing the groundwater table, etc. ${ }^{1}$. In India, about $37,000 \mathrm{~km}^{3}$ of water and $13.5 \times 10^{9}$ tonnes of sediments are transported into the sea by rivers ${ }^{2-4}$. The Cauvery, Vaigai and Thamirabarani are the three major rivers of southern Tamil Nadu, India. The Vaigai flows through Theni, Madurai, Sivagangai and Ramanathapuram districts of the state. The inhabitants of Tirunelveli and Tuticorin depend on the Thamirabarani for water ${ }^{5,6}$. The Cauvery provides irrigation for five major districts of Tamil Nadu, viz. Karur, Namakkal, Tiruchirappalli, Thanjavur and Nagapattinam ${ }^{7,8}$.

*For correspondence. (e-mail: drrajaram69@rediffmail.com)
The source of the heavy metals could be traced to the weathering of rocks, and these metals get accumulated in the aquatic ecosystems. Due to urbanization and anthropogenic activities, the concentration of heavy metals has increased $^{9-11}$. These changes create unfavourable conditions for the survival of living organisms by altering the physicochemical parameters, nutrient levels, and water quality index. About $99 \%$ of heavy metals deposited in river sediments are from various routes ${ }^{12}$. Bioaccumulation of heavy metals and bio-magnification occur through the food-chain. Finally, when the river water reaches the sea, the marine ecosystem gets polluted with these toxic metals, ultimately causing health issues in human beings who rely upon the marine organisms for their $\operatorname{diet}^{13-15}$.

Not only industrial and agricultural pollutants, activities like idol immersion play an important role in river pollution. In India, every year during September-October, at the end of the festival season idols of Gods/Goddesses are immersed into the rivers, lakes, ponds, etc. ${ }^{16}$. Most of the idols are made of clay, plaster of Paris, cement and decorated by paint, clothes, bamboo and varnishes ${ }^{17,18}$ which contain metals like lead, cadmium, copper, iron, zinc, chromium as well as different organic and inorganic substances. After idol immersion, these chemicals are dissolved in water and settle down as sediments eventually transferred to the food-chain ${ }^{19-22}$. Idol immersion contaminates the water bodies which are the source of irrigation. Thus crops are affected by heavy metals and there is a major impact of ecotoxicology $y^{23}$.

Tamil Nadu is one of the diverse biospheres in India, consisting of both biologically and economically important zones. Currently, several anthropogenic activities are disturbing the life of aquatic organisms ${ }^{24,25}$. The present study was conducted in River Cauvery from Mettur dam to Poombuhar, and a branch of the river called Kollidam from Trichy, Mookumbu to Pazhayar. We examined the impact of immersion of idols in South India, especially in the Cauvery river basin. The objectives of the study were as follows: (i) Assessment of concentration of both essential $(\mathrm{Cu}, \mathrm{Zn})$ and non-essential $(\mathrm{Cd}, \mathrm{Pb})$ elements in river samples before and after idol immersion. (ii) Comparison of metal concentrations before and after the immersion of 
Table 1. Study area description and geographical coordinates

\begin{tabular}{|c|c|c|c|}
\hline Station no. & Possible activities causing pollution & Latitude & Longitude \\
\hline \multicolumn{4}{|c|}{ Description of Cauvery river sampling sites } \\
\hline $\mathrm{C} 1$ & Textiles industries and spinning mills & $77^{\circ} 75^{\prime} 98^{\prime \prime}$ & $11^{\circ} 65^{\prime} 04^{\prime \prime}$ \\
\hline $\mathrm{C} 2$ & Mettur Thermal Power Station dump & $77^{\circ} 74^{\prime} 37^{\prime \prime}$ & $11^{\circ} 57^{\prime} 60^{\prime \prime}$ \\
\hline $\mathrm{C} 3$ & Textiles industries and spinning mills & $77^{\circ} 69^{\prime} 06^{\prime \prime}$ & $11^{\circ} 45^{\prime} 16^{\prime \prime}$ \\
\hline $\mathrm{C} 4$ & Textiles industries and spinning mills & $77^{\circ} 43^{\prime} 37^{\prime \prime}$ & $11^{\circ} 45^{\prime} 16^{\prime \prime}$ \\
\hline $\mathrm{C} 5$ & Textiles industries and spinning mills & $77^{\circ} 88^{\prime} 98^{\prime \prime}$ & $11^{\circ} 07^{\prime} 76^{\prime \prime}$ \\
\hline C6 & Dye and bleaching industries & $78^{\circ} 23^{\prime} 51^{\prime \prime}$ & $10^{\circ} 96^{\prime} 02^{\prime \prime}$ \\
\hline $\mathrm{C} 7$ & Dye and bleaching industries & $78^{\circ} 41^{\prime} 83^{\prime \prime}$ & $10^{\circ} 94^{\prime} 76^{\prime \prime}$ \\
\hline $\mathrm{C} 8$ & Medical waste and sewage & $78^{\circ} 57^{\prime} 87^{\prime \prime}$ & $10^{\circ} 88^{\prime} 25^{\prime \prime}$ \\
\hline C9 & Medical waste and sewage & $78^{\circ} 69^{\prime} 85^{\prime \prime}$ & $10^{\circ} 83^{\prime} 84^{\prime \prime}$ \\
\hline $\mathrm{C} 10$ & Agricultural run-off and domestic sewage & $78^{\circ} 81^{\prime} 90^{\prime \prime}$ & $10^{\circ} 83^{\prime} 03^{\prime \prime}$ \\
\hline $\mathrm{C} 11$ & Agricultural run-off and domestic sewage & $78^{\circ} 94^{\prime} 99^{\prime \prime}$ & $10^{\circ} 85^{\prime} 47^{\prime \prime}$ \\
\hline $\mathrm{C} 12$ & Agricultural run-off and domestic sewage & $79^{\circ} 08^{\prime} 58^{\prime \prime}$ & $10^{\circ} 87^{\prime} 60^{\prime \prime}$ \\
\hline $\mathrm{C} 13$ & Agricultural run-off and domestic sewage & $79^{\circ} 25^{\prime} 54^{\prime \prime}$ & $10^{\circ} 94^{\prime} 14^{\prime \prime}$ \\
\hline $\mathrm{C} 14$ & Agricultural run-off and domestic sewage & $79^{\circ} 38^{\prime} 30^{\prime \prime}$ & $10^{\circ} 96^{\prime} 99^{\prime \prime}$ \\
\hline $\mathrm{C} 15$ & Agricultural run-off and domestic sewage & $79^{\circ} 49^{\prime} 23^{\prime \prime}$ & $11^{\circ} 03^{\prime} 39^{\prime \prime}$ \\
\hline $\mathrm{C} 16$ & Agricultural run-off and domestic sewage & $79^{\circ} 56^{\prime} 14^{\prime \prime}$ & $11^{\circ} 08^{\prime} 04^{\prime \prime}$ \\
\hline $\mathrm{C} 17$ & Agricultural run-off and domestic sewage & $79^{\circ} 65^{\prime} 40^{\prime \prime}$ & $11^{\circ} 10^{\prime} 48^{\prime \prime}$ \\
\hline $\mathrm{C} 18$ & Agricultural run-off and domestic sewage & $79^{\circ} 78^{\prime} 16^{\prime \prime}$ & $11^{\circ} 14^{\prime} 95^{\prime \prime}$ \\
\hline $\mathrm{C} 19$ & Agricultural run-off and domestic sewage & $79^{\circ} 81^{\prime} 94^{\prime \prime}$ & $11^{\circ} 14^{\prime} 51^{\prime \prime}$ \\
\hline $\mathrm{C} 20$ & Agricultural run-off, domestic sewage and fishing activities & $79^{\circ} 85^{\prime} 71^{\prime \prime}$ & $11^{\circ} 13^{\prime} 62^{\prime \prime}$ \\
\hline \multicolumn{4}{|c|}{ Description of Kollidam river sampling sites } \\
\hline K1 & Agricultural run-off and sewage & $78^{\circ} 70^{\prime} 36^{\prime \prime}$ & $10^{\circ} 87^{\prime} 25^{\prime \prime}$ \\
\hline $\mathrm{K} 2$ & Agricultural run-off and sewage & $78^{\circ} 83^{\prime} 33^{\prime \prime}$ & $10^{\circ} 84^{\prime} 21^{\prime \prime}$ \\
\hline $\mathrm{K} 3$ & Agricultural run-off and sewage & $78^{\circ} 97^{\prime} 82^{\prime \prime}$ & $10^{\circ} 88^{\prime} 67^{\prime \prime}$ \\
\hline K4 & Agricultural run-off and sewage & $79^{\circ} 03^{\prime} 70^{\prime \prime}$ & $10^{\circ} 88^{\prime} 24^{\prime \prime}$ \\
\hline K5 & Sand mining & $79^{\circ} 36^{\prime} 07^{\prime \prime}$ & $11^{\circ} 05^{\prime} 36^{\prime \prime}$ \\
\hline K6 & Sand mining & $79^{\circ} 45^{\prime} 48^{\prime \prime}$ & $11^{\circ} 13^{\prime} 49^{\prime \prime}$ \\
\hline K7 & Sand mining & $79^{\circ} 61^{\prime} 48^{\prime \prime}$ & $11^{\circ} 24^{\prime} 10^{\prime \prime}$ \\
\hline K8 & Sewage, plastics household waste & $79^{\circ} 70^{\prime} 71^{\prime \prime}$ & $11^{\circ} 33^{\prime} 47^{\prime \prime}$ \\
\hline K9 & Fishing is major activity & $79^{\circ} 83^{\prime} 02^{\prime \prime}$ & $11^{\circ} 35^{\prime} 60^{\prime \prime}$ \\
\hline
\end{tabular}

idols. (iii) Identification of the potential source of heavy metals. (iv) Assessment of pollution load index and geoaccumulation index of analysed elements.

\section{Materials and methods}

\section{Description of the study area}

The Cauvery is a predominant river system of South India that provides water to most areas of Karnataka and Tamil Nadu. In the subcontinent, the Cauvery is the eighth longest river $^{26}$. It influences the traditional life of the people in peninsular India, and also plays a major role in the flourishment of the region ${ }^{27}$. The Cauvery has 29 crucial creeks and branches. Water flow occurs during the southwest monsoon and northeast monsoons, except in Kodagu district, Karnataka. The temperature of the river basin is approximately $25^{\circ} \mathrm{C}$ and decreases at higher elevation ${ }^{26}$. The study area is surrounded by several industrial estates like textile, steel and automobiles. Agricultural activity is also present, which contributes to the economy of the people. Table 1 describes the exact geo-coordinates of the sampling points and possible source of pollution.

\section{Sampling}

To understand the impact of idol immersion, two different samples were collected, i.e. before and after the immersion. Triplicate water and sediment samples in onemonth intervals were collected before (August 2018) and after (October 2018) idol immersions (Figure 1). One litre of water sample from each station was collected in acid-washed polystyrene containers and $1 \mathrm{ml}$ of concentrated nitric acid was added ${ }^{28}$. A PVC pipe was used to extract the top 2-cm layer of the soil, and the samples were packed in sterilized zip-lock polythene covers. All the collected samples were stored at $4^{\circ} \mathrm{C}$ until further analysis $^{29}$.

\section{Sample preparation}

Water samples were filtered using the Millipore filtration unit to avoid debris-mediated contamination. In order to acidify the sample and to chelate the available elements, $1 \%$ freshly prepared APDC solution was added to the water sample. In addition, MIBK solvent was added to extract the metal-APDC complex. Finally, the samples containing organic layer were re-extracted using $50 \% \mathrm{HNO}_{3}$. 

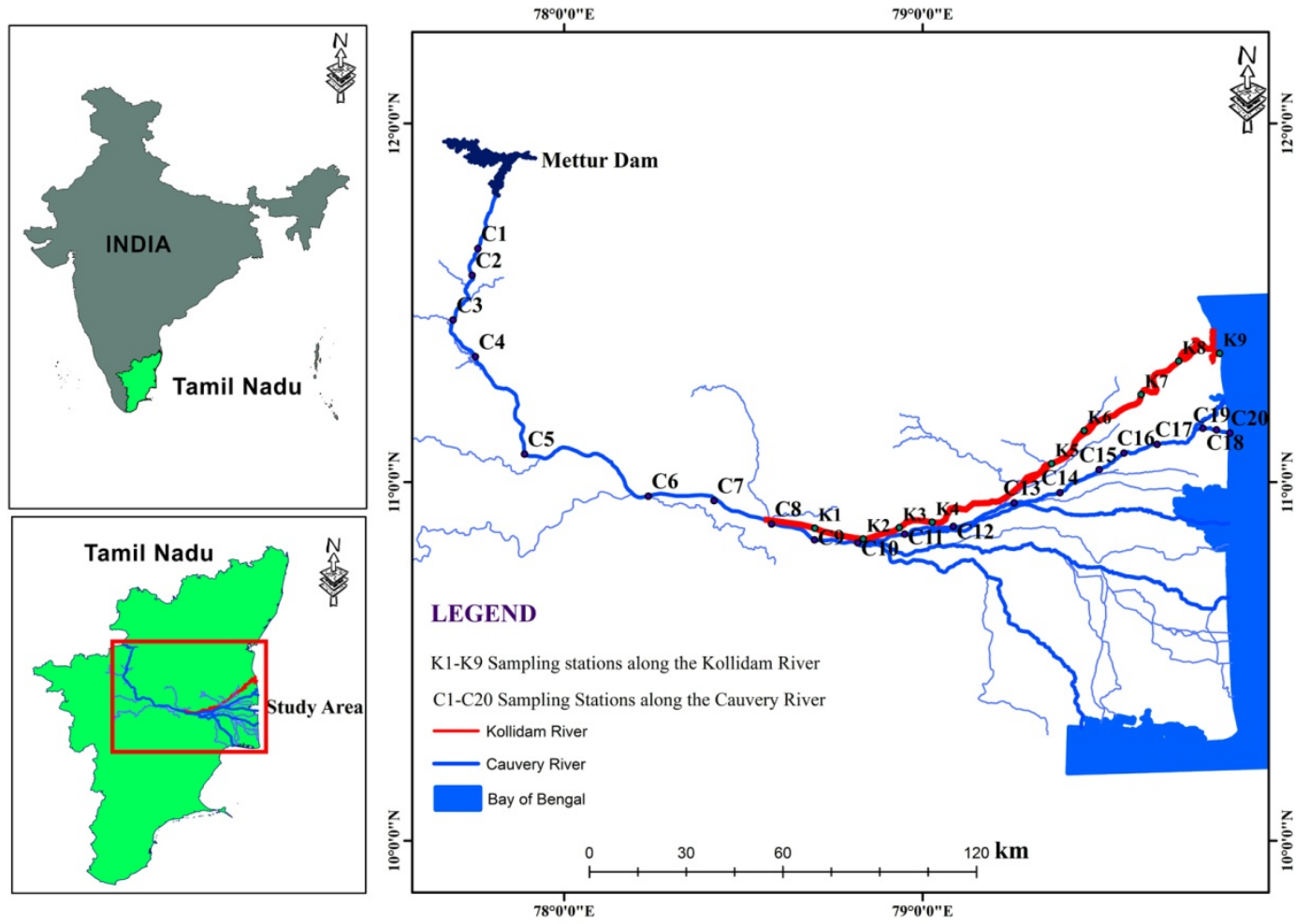

Figure 1. Location of sampling sites along the Cauvery and Kollidam rivers (Cauvery basin).

The extract was made up to $25 \mathrm{ml}$ by adding distilled water $^{30}$. The soil samples were air-dried and ground into a fine powder to perform acid digestion ${ }^{31}$. For this, $1 \mathrm{~g}$ of powdered soil sample was digested using $10 \mathrm{ml}$ of acid reagent $\left(\mathrm{HNO}_{3}, \mathrm{H}_{2} \mathrm{SO}_{4}\right.$, and $\mathrm{HCLO}_{4}$ in the ratio $5: 2: 1)$ at $60^{\circ}-100^{\circ} \mathrm{C}$ on a hot plate until the volume was reduced to $1 \mathrm{ml}$. Then $5 \mathrm{ml}$ of $2 \mathrm{~N}$ hydrochloric acid was added to perform complete digestion. The solution was filtered and made up to $25 \mathrm{ml}$ by adding distilled water. Following the above procedure blank samples were prepared $^{30}$.

\section{Statistical analysis}

One-way ANOVA was performed using SPSS software to determine the concentration of heavy metals in the water and soil samples at $0.05 \%$ level. The source of heavy metals was identified by multivariate statistical analysis such as principal component analysis (PCA) using PAST software.

\section{Assessment of health of the study area}

To assess the pollution status of the study area, we used the geo-accumulation index $\left(I_{\text {geo }}\right)$, pollution load index (PLI) and contamination factor (CF).

$$
I_{\text {geo }}=\log 2\left(\frac{C_{\mathrm{n}}}{1.5 \times B_{\mathrm{n}}}\right) \text {, }
$$

where $C_{\mathrm{n}}$ is the heavy metal concentration in the sediment, and $B_{\mathrm{n}}$ is the background value of element in the earth crust. A factor of 1.5 was introduced to compensate the background content due to lithogenic effects ${ }^{24}$.

$$
\mathrm{CF}_{i}=C_{i} / B_{i}
$$

where $C_{i}$ is the concentration of individual elements studied and $B_{i}$ is the background concentration of a particular element.

$$
\mathrm{PLI}=\left(\mathrm{CF}_{1} \times \mathrm{CF}_{2} \times \mathrm{CF}_{3} \times \ldots \mathrm{CF}_{n}\right) 1 / n .
$$

The PLI values were interpreted in two levels as polluted $(\mathrm{PLI}>1)$ and unpolluted $(\mathrm{PLI}<1)^{25}$.

\section{Quality assessment and assurance of the instrument}

All the analyses of $\mathrm{Cu}, \mathrm{Cd}, \mathrm{Pb}$ and $\mathrm{Zn}$ were performed using atomic absorption spectrophotometer (AA7000Shimadzu, Japan) based on the standardized laboratory $\operatorname{method}^{29,30}$. The air-acetylene combination was maintained in all samples. According to the manufacture's protocol, all the basic spectrometric corrections were 
RESEARCH ARTICLES

Table 2. Variation of metal concentration in Kollidam water (mg/l) and soil (mg/kg)

\begin{tabular}{|c|c|c|c|c|c|c|c|c|c|}
\hline \multirow[b]{2}{*}{ Sample } & \multirow[b]{2}{*}{ Station } & \multicolumn{2}{|c|}{$\mathrm{Cu}$} & \multicolumn{2}{|c|}{$\mathrm{Cd}$} & \multicolumn{2}{|r|}{$\mathrm{Pb}$} & \multicolumn{2}{|c|}{$\mathrm{Zn}$} \\
\hline & & Before & After & Before & After & Before & After & Before & After \\
\hline \multirow[t]{9}{*}{ Water } & K1 & $0.3 \pm 0.21$ & $0.13 \pm 0.04$ & $0.27 \pm 0.15$ & $0.24 \pm 0.08$ & ND & ND & ND & ND \\
\hline & $\mathrm{K} 2$ & ND & ND & $0.45 \pm 0.12$ & $0.25 \pm 0.05$ & ND & ND & ND & ND \\
\hline & K3 & ND & ND & $0.62 \pm 0.11$ & $0.04 \pm 0.06$ & ND & ND & ND & ND \\
\hline & K4 & ND & ND & $0.44 \pm 0.1$ & $0.24 \pm 0.11$ & ND & ND & ND & ND \\
\hline & K5 & ND & ND & $0.36 \pm 0.08$ & $0.31 \pm 0.10$ & ND & $2.48 \pm 0.50$ & ND & ND \\
\hline & K6 & ND & ND & $0.18 \pm 0.04$ & $0.06 \pm 0.07$ & ND & $2.88 \pm 1.63$ & ND & ND \\
\hline & K7 & ND & ND & $0.32 \pm 0.1$ & $0.12 \pm 0.11$ & ND & $0.65 \pm 0.10$ & ND & ND \\
\hline & K8 & ND & ND & $0.37 \pm 0.06$ & $0.11 \pm 0.04$ & ND & $0.52 \pm 0.09$ & ND & ND \\
\hline & K9 & ND & ND & $0.27 \pm 0.06$ & $0.14 \pm 0.07$ & ND & $0.52 \pm 0.09$ & ND & ND \\
\hline \multirow[t]{9}{*}{ Soil } & K1 & $5.06 \pm 1.29$ & $2.89 \pm 0.8$ & $5.69 \pm 1$ & $1.33 \pm 0.58$ & ND & $4.79 \pm 0.5$ & $0.32 \pm 0.1$ & $6.89 \pm 0.71$ \\
\hline & K2 & $6.38 \pm 1.16$ & $2.73 \pm 1.2$ & $1.87 \pm 0.65$ & $2.12 \pm 0.2$ & ND & $0.85 \pm 0.1$ & $5.01 \pm 1.1$ & $0.16 \pm 0.1$ \\
\hline & K3 & $4.68 \pm 1.09$ & $2.53 \pm 0.71$ & $2.52 \pm 1.01$ & $1.42 \pm 0.42$ & ND & $0.74 \pm 0.09$ & $3.13 \pm 0.96$ & $0.11 \pm 0.05$ \\
\hline & K4 & $5.88 \pm 0.95$ & $2.77 \pm 0.67$ & $0.85 \pm 0.13$ & ND & ND & $1.12 \pm 0.23$ & $6.42 \pm 0.8$ & ND \\
\hline & K5 & $4.57 \pm 0.87$ & $2.03 \pm 0.44$ & $1.57 \pm 0.53$ & ND & ND & $1.92 \pm 0.2$ & $2.65 \pm 0.67$ & $5.64 \pm 0.78$ \\
\hline & K6 & $3.39 \pm 0.22$ & $3.11 \pm 1.03$ & $1.74 \pm 0.86$ & ND & ND & $1.69 \pm 0.45$ & $4.89 \pm 1.99$ & $3.58 \pm 1.26$ \\
\hline & K7 & $4.54 \pm 0.63$ & $3.85 \pm 0.8$ & $5.14 \pm 1.14$ & ND & ND & $0.68 \pm 0.11$ & $0.33 \pm 0.1$ & $2.15 \pm 0.2$ \\
\hline & K8 & $5.39 \pm 0.91$ & $5.36 \pm 1.04$ & $1.86 \pm 0.55$ & ND & ND & $1.65 \pm 0.37$ & $7.21 \pm 1.1$ & $3.7 \pm 0.56$ \\
\hline & K9 & $5.11 \pm 0.48$ & $3.03 \pm 0.87$ & $5.76 \pm 1.32$ & $0.06 \pm 0.08$ & ND & $7.62 \pm 0.76$ & $3.26 \pm 0.95$ & $4.2 \pm 0.36$ \\
\hline
\end{tabular}

$\mathrm{ND}$, Not detectable; values represent mean \pm standard deviation.

performed. Calibrations of each element were settled by standard solutions made by stepwise dilution of the stock solution. The absorption wavelength was $228.8 \mathrm{~nm}$ for $\mathrm{Cd}, 324.7 \mathrm{~nm}$ for $\mathrm{Cu}, 217.0 \mathrm{~nm}$ for $\mathrm{Pb}$ and $213.9 \mathrm{~nm}$ for $\mathrm{Zn}$.

\section{Results and discussion}

\section{Heavy metal concentration in Kollidam river samples}

Table 2 gives the concentration level of metals before and after idol immersion. Concentration of metals in the Kollidam sediment samples ranged from $3.39 \pm 0.22$ to $6.38 \pm 0.22 \mathrm{mg} / \mathrm{g}$ for $\mathrm{Cu}, 0.85 \pm 0.13$ to $5.69 \pm 0.99 \mathrm{mg} / \mathrm{g}$ for $\mathrm{Cd}$, no traces of $\mathrm{Pb}$ and $0.32 \pm 0.10$ to $9.21 \pm$ $1.10 \mathrm{mg} / \mathrm{g}$ for $\mathrm{Zn}$. It varied significantly after idol immersion ranging from $2.03 \pm 0.44$ to $5.36 \pm 1.04 \mathrm{mg} / \mathrm{g}$ for $\mathrm{Cu}$, $0.06 \pm 0.08$ to $2.12 \pm 0.20 \mathrm{mg} / \mathrm{g}$ for $\mathrm{Cd}, 0.68 \pm 0.11$ to $7.62 \pm 0.76 \mathrm{mg} / \mathrm{l}$ for $\mathrm{Pb}$ and $0.11 \pm 0.05$ to $6.89 \pm$ $0.71 \mathrm{mg} / \mathrm{g}$ for $\mathrm{Zn}$. Before idol immersion in the Kollidam river water, the concentration range of $\mathrm{Cu}$ and $\mathrm{Cd}$ was 0 to $0.30 \pm 0.21 \mathrm{mg} / 1$ and $0.18 \pm 0.04$ to $0.62 \pm 0.11 \mathrm{mg} / \mathrm{l}$ ) respectively. However, no traces of $\mathrm{Pb}$ and $\mathrm{Zn}$ were found in the samples. The concentration of heavy metals varied with respect to different stations, which could be attributed to a direct relation with idol immersion activity or by any other source of pollution.

In the Kollidam samples the trend of metal distribution was entirely different. Before idol immersion traces of $\mathrm{Cd}$ alone were detected in the water sample; $\mathrm{Pb}>\mathrm{Cd}>$ $\mathrm{Cu}>$ no $\mathrm{Zn}$ (after idol immersion). In the soil samples, $\mathrm{Cu}>\mathrm{Zn}>\mathrm{Cd}>$ no $\mathrm{Pb}$ (before idol immersion); $\mathrm{Cu}>$ $\mathrm{Zn}>\mathrm{Pb}>\mathrm{Cd}$ (after idol immersion). In order to understand the significant impact of idol immersion in the both samples, metal concentration was evaluated using statistical analysis (non-parametric). The water samples showed significant variation in $\mathrm{Cd}$ and $\mathrm{Pb}$ concentration before and after idol immersion $(P<0.01)$. Similarly, strong statistical significance was observed for $\mathrm{Cu}, \mathrm{Cd}$, and $\mathrm{Pb}$ in the collected soil samples before and after idol immersion $(P<0.01)$.

In water samples before and after idol immersion, the mean concentration of $\mathrm{Cu}$ and $\mathrm{Cd}$ was higher than the BIS, IS-10500 (Bureau of Indian Standards); 2012, WHO (World Health Organization) and CPCB (Central Pollution Control Board) standards. Although no traces of $\mathrm{Pb}$ were recorded before idol immersion in both samples, after immersion $\mathrm{Pb}$ levels were elevated to several fold than the BIS, IS-10500 in water and less than the Canadian Environmental Quality Guidelines (CEQG, 2001) in the sediments. During the entire study period, Zn concentration was recorded below the permissible limits given by BIS, IS-10500 and CEQG 2001 (Table 3).

\section{Heavy metal concentration in Cauvery River samples}

Tables 4 and 5 list the mean and range of metal concentration among different sites of River Cauvery before and 
Table 3. Permissible level of different metals in water and soil samples recommended by national and international agencies

\begin{tabular}{lcccc}
\hline Sample & Metal & Present study & BIS, IS-10500; 2012 & WHO/CPCB \\
\hline Water (mg/l) & $\mathrm{Cu}$ & $0.20-1.73$ & 0.05 & 2 \\
& $\mathrm{Cd}$ & $0.13-2.02$ & 0.003 & 0.003 \\
& $\mathrm{~Pb}$ & $0.52-2.88$ & 0.01 & 0.01 \\
& $\mathrm{Zn}$ & $\mathrm{ND}$ & 5 & No health-based guideline \\
& & & value has been proposed \\
Soil (mg/kg) & & & - \\
& Metal & Present study & CEQG & - \\
& $\mathrm{Cu}$ & $1.53-16.39$ & 18.7 & - \\
& $\mathrm{Cd}$ & $0.85-7.21$ & 0.7 & - \\
& $\mathrm{Pb}$ & $0.17-7.62$ & 30.2 & \\
& $\mathrm{Zn}$ & $0.32-34.70$ & 124 & Central Pollution
\end{tabular}

BIS, Bureau of Indian Standards; WHO, World Health Organization; CPCB, Central Pollution Control Board; CEQG, Canadian Environmental Quality Guidelines.

Table 4. Distribution of different elements in water samples $(\mathrm{mg} / \mathrm{l})$ of the Cauvery basin

\begin{tabular}{|c|c|c|c|c|c|c|c|c|}
\hline \multirow[b]{2}{*}{ Station } & \multicolumn{2}{|c|}{$\mathrm{Cu}$} & \multicolumn{2}{|c|}{$\mathrm{Cd}$} & \multicolumn{2}{|c|}{$\mathrm{Pb}$} & \multicolumn{2}{|c|}{$\mathrm{Zn}$} \\
\hline & Before & After & Before & After & Before & After & Before & After \\
\hline $\mathrm{C} 1$ & $0.89 \pm 0.08$ & $0.21 \pm 0.03$ & $0.6 \pm 0.13$ & $0.19 \pm 0.06$ & ND & $0.18 \pm 0.05$ & ND & ND \\
\hline $\mathrm{C} 2$ & $1.57 \pm 0.27$ & $0.25 \pm 0.11$ & $0.5 \pm 0.36$ & $0.31 \pm 0.1$ & ND & $0.85 \pm 0.10$ & ND & ND \\
\hline $\mathrm{C} 3$ & $1.73 \pm 0.40$ & $0.37 \pm 0.15$ & $2.02 \pm 0.50$ & $0.25 \pm 0.1$ & ND & $1.57 \pm 0.63$ & ND & ND \\
\hline $\mathrm{C} 4$ & $0.56 \pm 0.12$ & $0.31 \pm 0.12$ & $0.63 \pm 0.15$ & $0.28 \pm 0.04$ & ND & $0.86 \pm 0.19$ & ND & ND \\
\hline $\mathrm{C} 5$ & $0.50 \pm 0.09$ & $0.23 \pm 0.10$ & $0.38 \pm 0.10$ & $0.27 \pm 0.05$ & ND & $0.65 \pm 0.10$ & ND & ND \\
\hline C6 & $0.34 \pm 0.06$ & $0.18 \pm 0.06$ & $0.53 \pm 0.15$ & $0.31 \pm 0.11$ & ND & $0.16 \pm 0.12$ & ND & ND \\
\hline $\mathrm{C} 7$ & $0.01 \pm 0.01$ & $0.2 \pm 0.11$ & $0.31 \pm 0.17$ & $0.23 \pm 0.04$ & ND & ND & ND & ND \\
\hline $\mathrm{C} 8$ & $0.33 \pm 0.20$ & $0.24 \pm 0.08$ & $0.68 \pm 0.38$ & $0.34 \pm 0.12$ & ND & ND & ND & ND \\
\hline C9 & $0.05 \pm 0.06$ & $0.25 \pm 0.08$ & $0.56 \pm 0.21$ & $0.28 \pm 0.04$ & ND & ND & ND & ND \\
\hline $\mathrm{C} 10$ & $0.24 \pm 0.06$ & $0.23 \pm 0.12$ & $0.36 \pm 0.2$ & $0.2 \pm 0.07$ & ND & ND & ND & ND \\
\hline $\mathrm{C} 11$ & $0.29 \pm 0.13$ & $0.17 \pm 0.05$ & $0.55 \pm 0.26$ & $0.24 \pm 0.05$ & ND & ND & ND & ND \\
\hline $\mathrm{C} 12$ & $0.24 \pm 0.09$ & $0.25 \pm 0.10$ & $0.77 \pm 0.14$ & $0.31 \pm 0.1$ & ND & ND & ND & ND \\
\hline $\mathrm{C} 13$ & $0.04 \pm 0.05$ & $0.14 \pm 0.11$ & $0.61 \pm 0.12$ & $0.16 \pm 0.09$ & ND & ND & ND & ND \\
\hline $\mathrm{C} 14$ & $0.07 \pm 0.10$ & $0.15 \pm 0.06$ & $0.56 \pm 0.1$ & $1.47 \pm 1.5$ & ND & ND & ND & ND \\
\hline $\mathrm{C} 15$ & $0.12 \pm 0.05$ & $0.09 \pm 0.07$ & $0.67 \pm 0.24$ & $0.45 \pm 0.51$ & ND & ND & ND & ND \\
\hline $\mathrm{C} 16$ & $0.04 \pm 0.06$ & $0.31 \pm 0.10$ & $0.77 \pm 0.21$ & $0.32 \pm 0.11$ & ND & ND & ND & ND \\
\hline $\mathrm{C} 17$ & $0.12 \pm 0.17$ & $0.17 \pm 0.10$ & $0.65 \pm 0.15$ & $0.19 \pm 0.08$ & ND & ND & ND & ND \\
\hline C18 & $0.05 \pm 0.08$ & $0.09 \pm 0.07$ & $0.67 \pm 0.09$ & $0.14 \pm 0.12$ & ND & ND & ND & ND \\
\hline C19 & $0.13 \pm 0.18$ & $0.12 \pm 0.13$ & $0.55 \pm 0.16$ & $0.09 \pm 0.15$ & ND & ND & ND & ND \\
\hline $\mathrm{C} 20$ & $0.11 \pm 0.08$ & $0.14 \pm 0.11$ & $0.61 \pm 0.15$ & $0.31 \pm 0.1$ & ND & ND & ND & ND \\
\hline
\end{tabular}

ND, Not detectable; values represent mean \pm standard deviation.

after the idol immersion. The abundance of metals in the Cauvery samples varied in the following order: $\mathrm{Cu}>\mathrm{Cd}$ $>$ no traces of $\mathrm{Pb}$ and $\mathrm{Zn}$ (before idol immersion); $\mathrm{Pb}>\mathrm{Cd}>\mathrm{Cu}>$ no traces of $\mathrm{Zn}$ (after idol immersion) in water, and $\mathrm{Zn}>\mathrm{Cu}>\mathrm{Cd}>\mathrm{Pb}$ (before idol immersion); $\mathrm{Cu}>\mathrm{Zn}>\mathrm{Pb}>\mathrm{Cd}$ (after idol immersion) in the soil. Heavy metal concentration in water and sediment samples of different sites in the Cauvery before idol immersion ranged from $0.01 \pm 0.01$ to $1.73 \pm 0.40 \mathrm{mg} / 1$ and $4.76 \pm 0.85$ to $16.39 \pm 2.17 \mathrm{mg} / \mathrm{kg}$ for copper, $0.31 \pm 0.17$ to $2.02 \pm 0.50 \mathrm{mg} / \mathrm{l}$ and $2.36 \pm 1.09$ to $7.21 \pm 1.17 \mathrm{mg} / \mathrm{kg}$ for cadmium, no traces and $0.72 \pm 0.79$ to $2.92 \pm$ $2.57 \mathrm{mg} / \mathrm{kg}$ for lead, and no traces and $2.62 \pm 1.25$ to $34.70 \pm 1.48 \mathrm{mg} / \mathrm{kg}$ for zinc. The concentration of metals in water and sediment samples after idol immersion varied as follows: $0.20 \pm 0.11$ to $0.37 \pm 0.15 \mathrm{mg} / 1$ and
$1.53 \pm 0.31$ to $9.58 \pm 0.86 \mathrm{mg} / \mathrm{kg}$ for copper, $0.09 \pm 0.15$ to $1.47 \pm 1.50 \mathrm{mg} / 1$ and $0.09 \pm 0.13$ to $2.20 \pm 0.40 \mathrm{mg} / \mathrm{kg}$ for cadmium, $0.16 \pm 0.12$ to $1.57 \pm 0.63 \mathrm{mg} / \mathrm{l}$ and $0.17 \pm 0.10$ to $3.80 \pm 0.67 \mathrm{mg} / \mathrm{kg}$ for lead, and no traces and $0.09 \pm 0.07$ to $14.57 \pm 1.10 \mathrm{mg} / \mathrm{kg}$ for zinc.

The water samples showed significant alteration variation in $\mathrm{Cd}$ concentration before and after idol immersion $(P<0.01)$. Strong statistical significance was observed for all the elements studied in the soil samples collected before and after idol immersion $(P<0.01)$. In most of the stations, $\mathrm{Cu}$ and $\mathrm{Cd}$ levels in the water samples were high while $\mathrm{Cu}, \mathrm{Cd}$ and $\mathrm{Zn}$ levels were high in sediment samples before idol immersion. In both water and sediment samples $\mathrm{Pb}$ concentration increased after idol immersion. Before and after immersion, the mean concentration of metals such as $\mathrm{Cu}, \mathrm{Cd}$ and $\mathrm{Pb}$ in the water 
RESEARCH ARTICLES

Table 5. Distribution of different elements in soil samples $(\mathrm{mg} / \mathrm{kg})$ of the Cauvery basin

\begin{tabular}{|c|c|c|c|c|c|c|c|c|}
\hline \multirow[b]{2}{*}{ Station } & \multicolumn{2}{|c|}{$\mathrm{Cu}$} & \multicolumn{2}{|c|}{$\mathrm{Cd}$} & \multicolumn{2}{|c|}{$\mathrm{Pb}$} & \multicolumn{2}{|c|}{$\mathrm{Zn}$} \\
\hline & Before & After & Before & After & Before & After & Before & After \\
\hline $\mathrm{C} 1$ & $12.75 \pm 2.62$ & $9.58 \pm 0.86$ & $3.97 \pm 1.54$ & $0.12 \pm 0.1$ & ND & $0.17 \pm 0.1$ & $34.7 \pm 1.48$ & $14.57 \pm 1.1$ \\
\hline $\mathrm{C} 3$ & $16.39 \pm 2.17$ & $5.06 \pm 0.71$ & $3.82 \pm 1.31$ & $0.12 \pm 0.04$ & ND & $0.33 \pm 0.11$ & $13.51 \pm 0.66$ & $2.24 \pm 0.31$ \\
\hline $\mathrm{C} 4$ & $12.27 \pm 2.19$ & $6.78 \pm 1.31$ & $3.36 \pm 1.12$ & $1.79 \pm 0.77$ & ND & $0.65 \pm 0.08$ & $10.13 \pm 0.98$ & $9.53 \pm 0.80$ \\
\hline $\mathrm{C} 5$ & $8.35 \pm 1.34$ & $4.61 \pm 0.66$ & $2.62 \pm 1.09$ & $0.09 \pm 0.13$ & ND & $0.52 \pm 0.11$ & $9.66 \pm 0.87$ & $1.63 \pm 0.60$ \\
\hline $\mathrm{C} 7$ & $12.31 \pm 2.6$ & $5.03 \pm 0.66$ & $2.97 \pm 1.05$ & $0.93 \pm 0.1$ & ND & $0.62 \pm 0.1$ & $15.29 \pm 1.21$ & $10.6 \pm 0.83$ \\
\hline $\mathrm{C} 8$ & $5.54 \pm 0.82$ & $4.31 \pm 1.02$ & $2.28 \pm 0.97$ & ND & ND & $3.24 \pm 1.08$ & $3.35 \pm 1.02$ & $1.67 \pm 0.76$ \\
\hline C9 & $5.90 \pm 1.35$ & $5.37 \pm 1.09$ & $3.58 \pm 1.05$ & ND & ND & $2.42 \pm 0.45$ & $9.93 \pm 1.64$ & $7.52 \pm 0.75$ \\
\hline $\mathrm{C} 10$ & $4.76 \pm 0.85$ & $3.66 \pm 0.45$ & $3.06 \pm 0.82$ & $0.24 \pm 0.1$ & ND & $0.68 \pm 0.1$ & $9.56 \pm 0.86$ & $1.45 \pm 0.52$ \\
\hline $\mathrm{C} 11$ & $5.95 \pm 2.03$ & $1.53 \pm 0.31$ & $3.28 \pm 1.10$ & $1.7 \pm 0.72$ & $2.92 \pm 2.57$ & $0.44 \pm 0.1$ & $3.27 \pm 1.03$ & ND \\
\hline $\mathrm{C} 12$ & $5.25 \pm 1.14$ & $4.2 \pm 0.63$ & $7.18 \pm 1.01$ & $0.52 \pm 0.2$ & $0.72 \pm 0.79$ & $0.44 \pm 0.1$ & $3.17 \pm 0.68$ & $1.77 \pm 0.70$ \\
\hline C13 & $5.17 \pm 1.59$ & $3.09 \pm 0.63$ & $3.67 \pm 0.8$ & $0.23 \pm 0.1$ & $1.86 \pm 0.46$ & $1.25 \pm 0.27$ & $2.62 \pm 1.25$ & $0.36 \pm 0.16$ \\
\hline $\mathrm{C} 14$ & $13.17 \pm 2.09$ & $3.68 \pm 0.52$ & $4.22 \pm 1.37$ & $0.73 \pm 0.1$ & ND & $3.8 \pm 0.67$ & $22.03 \pm 1.36$ & $0.64 \pm 0.30$ \\
\hline $\mathrm{C} 16$ & $10.84 \pm 2.07$ & $3.93 \pm 0.63$ & $3.72 \pm 1.09$ & $0.31 \pm 0.1$ & ND & $0.66 \pm 0.12$ & $15.77 \pm 1.38$ & $3.58 \pm 0.83$ \\
\hline $\mathrm{C} 17$ & $8.13 \pm 1.48$ & $3.53 \pm 1.0$ & $4.87 \pm 1.36$ & $0.25 \pm 0.09$ & ND & $1.59 \pm 0.6$ & $6.33 \pm 1.01$ & ND \\
\hline $\mathrm{C} 18$ & $5.51 \pm 0.57$ & $2.31 \pm 0.33$ & $7.21 \pm 1.17$ & $0.15 \pm 0.05$ & ND & $1.9 \pm 0.44$ & $4.63 \pm 0.84$ & $2.74 \pm 0.66$ \\
\hline C19 & $11.23 \pm 1.31$ & $8.36 \pm 0.95$ & $4.63 \pm 1.11$ & $0.54 \pm 0.15$ & ND & $0.26 \pm 0.08$ & $13.44 \pm 1.21$ & $9.40 \pm 1.00$ \\
\hline $\mathrm{C} 20$ & $6.32 \pm 1.15$ & $2.63 \pm 0.56$ & $2.36 \pm 1.09$ & $2.20 \pm 0.40$ & ND & $0.63 \pm 0.11$ & $6.84 \pm 1.05$ & ND \\
\hline
\end{tabular}

ND, Not detectable; Values represent mean \pm standard deviation.

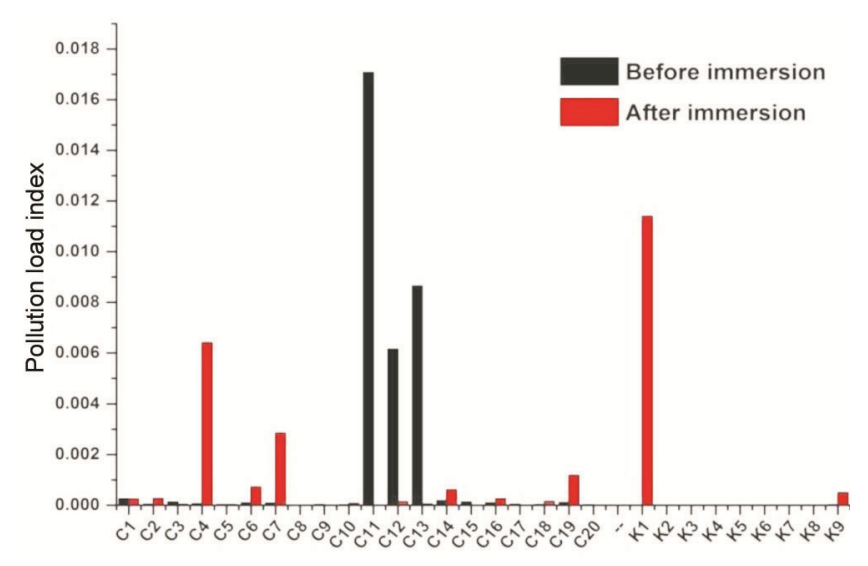

Figure 2. Pollution load index of different elements studied before and after idol immersion across the Cauvery river basin.

samples was relatively higher than the permissible limits of drinking water quality of BIS standards and WHO (Table 3).

The metals like $\mathrm{Cu}$ and $\mathrm{Cd}$ showed elevated levels in water samples of the Cauvery river point before idol immersion than after immersion. The same pattern was observed for metals such as $\mathrm{Cu}, \mathrm{Cd}$ and $\mathrm{Zn}$ in the sediments during the entire study period. These might be influenced by industrial activities, municipal waste, untreated effluents from the nearby SIPCOT industries and agricultural activities. In Tamil Nadu, the Cauvery delta is the major contributor to paddy irrigation. In the due course of time, tonnes of contaminated forms of $\mathrm{Cu}$, $\mathrm{Cd}, \mathrm{Pb}$ and $\mathrm{Zn}$ as insecticides and fertilizers were directly applied to land ${ }^{32,33}$. This has increased two to three-fold during the past 20 years ${ }^{34}$.
A unique pattern of $\mathrm{Pb}$ distribution was observed during the study. Among the 20 stations of the Cauvery, only a few stations $(\mathrm{C} 1-\mathrm{C} 5)$ were reported with elevated $\mathrm{Pb}$ concentration in water. These stations are rich in industrial sites, where lead and its components are widely used for several purposes, e.g. lead acetate (dyeing of textiles, insecticides, chrome pigments), lead chromate (pigment in plastics), lead tetrafluoroborate (salt for electroplating), lead molybdenum chromate (pigments) and lead phosphate (stabilizing agent in plastics) ${ }^{35-37}$. According to the recent report by Shalini ${ }^{38}$, around 30,000 idols are immersed into the Hussain Sagar lake every year that contain $10 \mu \mathrm{g}$ lead $/ \mathrm{kg}$ of paint ${ }^{38}$. The drastic increase in the concentration of $\mathrm{Pb}$ in water and sediment samples is evidence that is due to idol immersion activities. This scenario is directly correlated with several studies in different parts of India ${ }^{38-40}$. Several studies have confirmed the elevated metal levels in specific aquatic bodies during the idol immersion activity throughout India.

\section{Principal component analysis}

In order to identify the potential sources of heavy metals in the present study, PCA method was employed to determine the concentration of heavy metals in the entire Cauvery river using eigen values and varimax rotation. Based on the concentration of all the elements analysed in the water samples, one principal component (PC) was extracted with $39.24 \%$ and $42.10 \%$ of total variance before and after immersion respectively. The coefficient of PC1 showed positive loading for $\mathrm{Cu}(0.707)$ and $\mathrm{Cd}$ (0.707) before immersion of the idols, also positive 


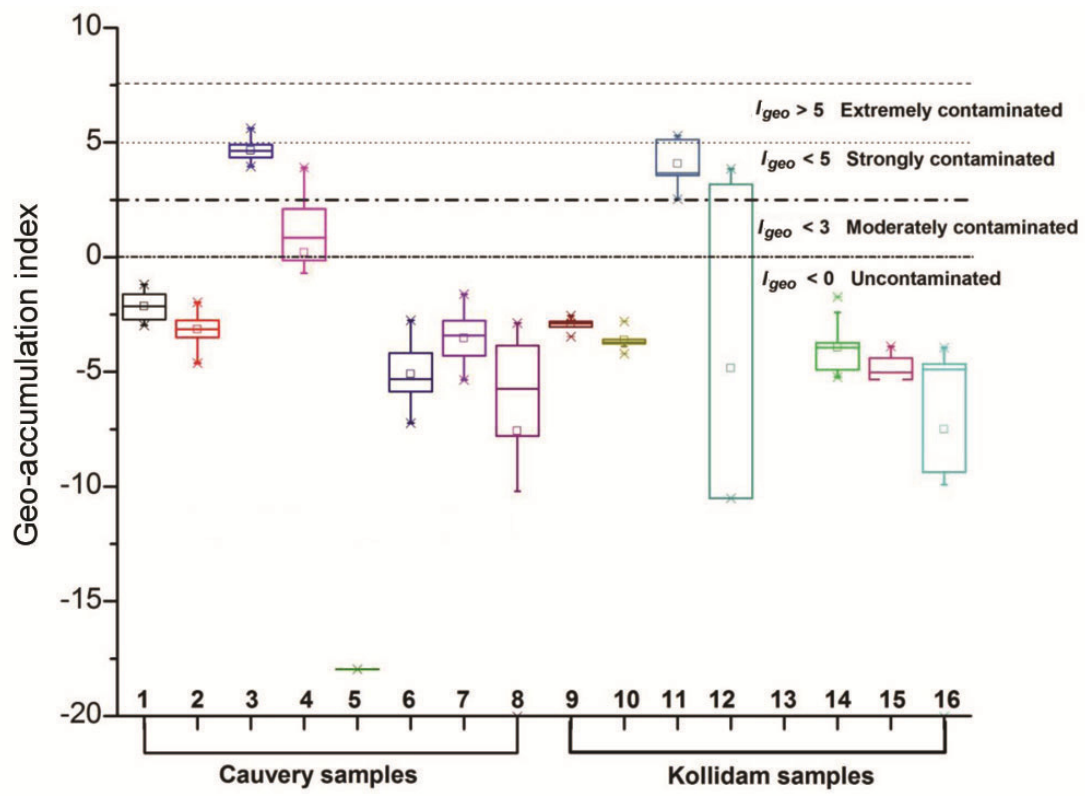

Figure 3. Geo-accumulation index of different elements studied before and after idol immersion across the Cauvery river basin.

loading was observed in $\mathrm{Cu}(0.695)$ and $\mathrm{Pb}(0.692)$ after immersion of the idols, thus indicating that the metals were from an anthropogenic origin. Followed by the pre- and post-idol immersions, sediment samples were extracted with two PCs showing $75.98 \%$ and $82.36 \%$ of the total variance. In PC1 for the period before and after immersion, $\mathrm{Cu}(0.613 ; 0.625)$ and $\mathrm{Zn}(0.614)$ showed strong positive correlation, while $\mathrm{Cd}$ and $\mathrm{Pb}$ were in negative loading; this shows the impact of lithogenic origin of metals. However, in PC2 both before and after immersion $\mathrm{Cd}$ had strong loading $(0.953 ; 0.740)$, which confirms the source of anthropogenic origin.

In the Kollidam river water samples, only one PC was extracted with an eigen value greater than one, which accounted for $31.89 \%$ and $35.05 \%$ of the total variance before and after immersion respectively. Before immersion of the idols, there was a strong positive loading for Cd (0.707), while after the immersion of idols there was a positive loading observed for $\mathrm{Cu}(0.690)$. Thus we can confirm that elevated metal concentration before immersion is linked to anthropogenic origin ${ }^{41}$, while after immersion it is directly linked with lithogenic sources. In case of sediment samples, pre-immersion activity was extracted by one PC with a total variance of $46.82 \%$, especially positive loading for $\mathrm{Zn}$ (0.684). Post-immersion, two PCs were extracted; however, PC1 alone could be contributed by an anthropogenic component having strong loading for both $\mathrm{Pb}(0.593)$ and $\mathrm{Zn}(0.660)$.

Moreover, the loading is evidence of alteration in the water bodies during idol immersion, especially the elevated $\mathrm{Pb}$ levels. The concentration of lead in unpolluted waters is less than $0.01 \mathrm{mg} / \mathrm{l}$, but an excessive amount of $1.57 \mathrm{mg} / 1$ was reported with an average of $0.71 \mathrm{mg} / \mathrm{l}$. This might be due to contaminants of untreated industrial effluents, improper handling of solid waste, battery manufacturing units, pigment industries, textile industries, and untreated effluents of sewage treatment plants. Elevated levels of some heavy metals and nutrients in the groundwater were reported from Mettur Dam; the possible sources are SIDCO Industrial Estate, thermal power plant, disposal of industrial effluents, municipal sewage and agrochemical leaching ${ }^{32}$. In the Cauvery river basin, monsoonal variation occurs that could be the possible source of pollutants, which might bring all the dumps and solid waste ${ }^{42}$. A significant change in metal concentration both before and after idol immersion was observed. However, the result lies within the BIS, IS-10500 limits.

\section{Assessment of metal pollution in river soil samples}

Figure 2 shows the calculated pollution load index (PLI) values of different metals during this study. The PLI values were relatively lower both before and after idol immersion in the Cauvery and Kollidam rivers. In all the sites PLI was less than 1, indicating least contamination of all the elements studied. The $I_{\text {geo }}$ was calculated using the metal concentration present in the soil samples of the study area (Figure 3). The $I_{\text {geo }}$ values for $\mathrm{Cu}, \mathrm{Pb}$, and $\mathrm{Zn}$ before and after idol immersion showed uncontaminated status of both river samples with reference to the background concentration of metals. Cd alone showed positive loading for all the sampling sites of both rivers (Cauvery - C1 to C20; Kollidam - K1 to K9) before idol immersion. However, the trend gradually altered after immersion and $I_{\text {geo }}$ values were between strongly contaminated and moderately contaminated zones. $\mathrm{CF}$ of $\mathrm{Cu}$, 


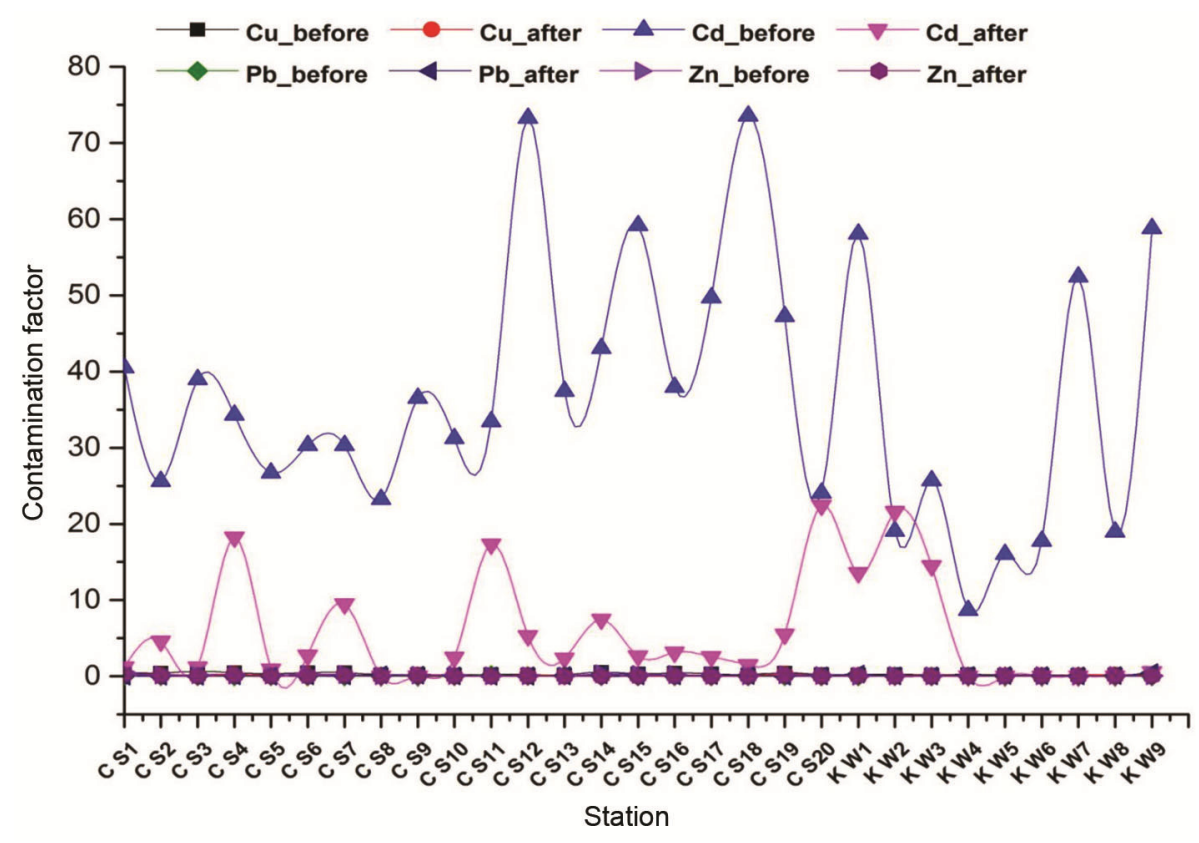

Figure 4. Contamination factor of different elements studied before and after idol immersion across the Cauvery river basin.

$\mathrm{Cd}, \mathrm{Pb}$, and $\mathrm{Zn}$. Considerable variation exists for $\mathrm{Cd}$ before immersion ranging from 23.27 to 73.57 in case of Cauvery river and 8.67 to 58.78 for Kollidam river samples (Figure 4). Such discrepancy might be influenced by water run-off during monsoon. Moreover, the obtained $I_{\text {geo }}$ values indicate that the rivers of Tamil Nadu are strongly influenced by $\mathrm{Cd}$-medicated toxicity that may impact human and aquatic life.

\section{Conclusion}

In recent decades due to several anthropogenic activities, the Cauvery river basin is being polluted by metals and other pollutants. Among them, seasonal idol immersion activity was reported as one of the main sources of pollution. In the present study traces of elements were detected in water and soil samples of the Cauvery river basin, which might be influenced by several anthropogenic activities. The concentration factor and geo-accumulation index revealed that soil samples of the Cauvery river basin were highly contaminated by $\mathrm{Cd}$ and less contaminated by other elements respectively. The immersion of the seasonal idol may not create any strong impacts on the distribution of metal in the Cauvery river because of its water flow. However, when the river water ends up into the sea, these metal pollutants arising from the immersions of idols would have a negative impact in the waters and sediments of the Bay of Bengal.

1. Dong, Z. R., Diversity of river morphology and diversity of bio-communities. J. Hydraul. Eng., 2003, 11, 1-6.
2. Meybeck, M., Total mineral dissolved transport by world major rivers/Transport en sels dissous des plus grands fleuves mondiaux. Hydrol. Sci. Bull., 1976, 21(2), 265-284.

3. Milliman, J. D. and Meade, R. H., World-wide delivery of river sediment to the oceans. J. Geol., 1983, 91(1), 1-21.

4. Alloway, B. J., Heavy metals in soils. In Sources of Heavy Metals and Metalloids in Soils (ed. Alloway B. J.), Blackie Academic and Professional Publisher, Springer, London, UK, 1995, p. 368.

5. Commission, C. W., Integrated Hydrological Data Book: Description of Different River Basins, Government of India, Ministry of Water Resources, River Development and Ganga Rejuvenation, and Central Water Commission, New Delhi, 2012, p. 31.

6. Kumarasamy, P., James, R. A., Dahms, H. U., Byeon, C. W. and Ramesh, R., Multivariate water quality assessment from the Tamiraparani river basin, southern India. Environ. Earth Sci., 2014, 71(5), 2441-2451.

7. Kalavathy, S., Sharma, T. R. and Sureshkumar, P., Water quality index of river Cauvery in Tiruchirappalli district, Tamil Nadu. Arch. Environ. Sci., 2011, 5, 55-61.

8. Premkumar, L., Unfolding disaster: a study of Chemplast Sanmar's toxic contamination in Mettur. Community Environmental Monitoring and Corporate Accountability Desk Programs of other Media (ed. Jayaram, N.), 2007, pp. 1-33; https://www.scribd.com/ document/126704364.

9. Falkenmark, M. and Widstrand, C., Population and water resources: a delicate balance. Popul. Bull., 1992, 47(3), 1.

10. Dhanakumar, S., Solaraj, G. and Mohanraj, R., Heavy metal partitioning in sediments and bioaccumulation in commercial fish species of three major reservoirs of river Cauvery delta region, India. Ecotoxicol. Environ. Saf., 2015, 113, 145-151.

11. Karbassi, A. R., Monavari, S. M., Bidhendi, G. R. N., Nouri, J. and Nematpour, K., Metal pollution assessment of sediment and water in the Shur River. Environ. Monit. Assess., 2008, 147(1-3), 107.

12. Alain, C. M. et al., Biogeodynamics of pollutants in soils and sediments: risk assessment of delayed and non-linear responses. In Time Frames: Soil and Sediments as Part of the Hydrological Cycle (eds Salomons, W. and Stigliani, W. M.), Springer, Verlag Berlin, Germany, 1995, p. 2. 


\section{RESEARCH ARTICLES}

13. Theofanis, Z. U., Astrid, S., Lidia, G. and Calmano, W. G., Contaminants in sediments: remobilisation and demobilization. Sci. Total. Environ., 2001, 266, 195-202.

14. Jezierska, B. and Witeska, M., Soil and water monitoring, protection and remediation. In The Metal Uptake and Accumulation in Fish Living in Polluted Waters (eds Twardowska, I. et al.), Springer, Poland, 2006, p. 110.

15. Udhayakumar, R., Manivannan, P., Raghu, K. and Vaideki, S., Assessment of physico-chemical characteristics of water in Tamilnadu. Ecotoxicol. Environ. Saf., 2016, 134, 474-477.

16. Bajpai, A., Pani, S., Jain, R. K. and Misra, S. M., Heavy metal contamination through idol immersion in a tropical lake. Ecol. Environ. Conserv., 2002, 8, 157-159.

17. Upadhyaya, A. and Bajpai, A., Comparison of physico-chemical parameters of various water bodies in and around Bhopal (MP). Asian J. Chem. Environ. Res., 2010, 3, 20-26.

18. Shukla, S. S., Effect of public awareness campaign in mitigating impact of religious activities on Bhopal lakes. In Image of water in religion, myths, literature, Switzerland, Global Biodiversity Forum, Abstr., 2004, vol. 2, p. 17.

19. Kaur, B. J., George, M. P. and Mishra, S., Water quality assessment of river Yamuna in Delhi stretch during Idol immersion. Int. J. Environ. Sci., 2013, 3(6), 2122.

20. Mukerjee, A., Religious activities and management of water bodies. Case study of idol immersion in context of urban lakes management. Int. Water Hist. Assoc., 2005, 3(3), 325.

21. Storelli, M. M., Storelli, A., D'addabbo, R., Marano, C., Bruno, R. and Marcotrigiano, G. O., Trace elements in loggerhead turtles (Caretta caretta) from the eastern Mediterranean Sea: overview and evaluation. Environ. Pollut., 2005, 135(1), 163-170.

22. Reddy, M. V., Babu, K. S., Balaram, V. and Satyanarayanan, M. Assessment of the effects of municipal sewage, immersed idols and boating on the heavy metal and other elemental pollution of surface water of the eutrophic Hussainsagar Lake (Hyderabad, India). Environ. Monit. Assess., 2012, 184(4), 1991-2000.

23. Reddy, M. V. and Kumar, A. V., Effects of Ganesh-idol immersion on some water quality parameters of Hussainsagar Lake. Curr. Sci., 2001, 81(11), 1412-1413.

24. Ganeshkumar, A., Arun, G., Vinothkumar, S. and Rajaram, R., Bioaccumulation and translocation efficacy of heavy metals by Rhizophora mucronata from tropical mangrove ecosystem, southeast coast of India. Ecohydrol. Hydrobiol., 2019, 19(1), 66-74.

25. Tomlinson, D. L., Wilson, J. G., Harris, C. R. and Jeffrey, D. W., Problems in the assessment of heavy-metal levels in estuaries and the formation of a pollution index. Helgol. Meeresunters., 1980 , 33(1), 566.

26. Jayaram, K. C., Kaveri riverine system: an environmental study. The Madras Science Foundation, Chennai, 2000, pp. 1-6.

27. Rajamani, R., Foreword. In Kaveri Riverine System: An environmental Study (ed. Jayaram, K. C.), Madras Science Foundation, Chennai, 1994.

28. Mathivanan, K. and Rajaram, R. D., Anthropogenic influences on toxic metals in water and sediment samples collected from industrially polluted Cuddalore coast, Southeast coast of India. Environ. Earth Sci., 2014, 72(4), 997-1010.

29. Rajaram, R., Ganeshkumar, A., Vinothkumar, S. and Rameshkumar, S., Multivariate statistical and GIS-based approaches for toxic metals in tropical mangrove ecosystem, southeast coast of India. Environ. Monit. Assess., 2017, 189(6), 288.

30. Arumugam, G., Rajendran, R., Shanmugam, V., Sethu, R. and Krishnamurthi, M., Flow of toxic metals in food-web components of tropical mangrove ecosystem, Southern India. Hum. Ecol. Risk Assess.: Int. J., 2018, 24(5), 1367-1387.

31. Singh, M., Müller, G. and Singh, I. B., Heavy metals in freshly deposited stream sediments of rivers associated with urbanisation of the Ganga Plain, India. Water Air Soil Pollut., 2002, 141(1-4), 35-54.

32. Jayakumar, R., Dhanakumar, S., Kalaiselvi, K. and Palanivel, M., Multivariate statistical analysis of heavy metals and other hydro chemical characteristics in industrially polluted groundwater resources of Mettur, India. Chem. Sci. Trans., 2015, 4(3), 728-735.

33. Mortvedt, J. J., Heavy metal contaminants in inorganic and organic fertilizers. Fertil. Res., 1996, 5-11.

34. Department of Environment, Government of Tamil Nadu, India, 2001, http://www.tnenvis.nic.in/DtProfiles/trichy (retrieved on 19 March 2009).

35. Agency for Toxic Substances and Disease Registry. Toxicological profile for lead (draft for public comment). US Department of Health and Human Services, Public Health Service, Atlanta, GA, USA, 2019.

36. Davidson, A. et al., Lead. In Ullmann's Encyclopedia of Industrial Chemistry, 2014; 10.1002/14356007.a15 193.pub3.

37. Carr, D. S., Spangenberg, W. C., Chronley, K. and Meshri, D. T., Lead compounds. In Kirk-Othmer Encycloped. Chem. Technol., 2000, 14, 1-26.

38. Shalini, P., Heavy metal contamination due to idol immersion in Hussain Sagar lake, Hyderabad, India. Int. J. Curr. Adv. Res., 2018, 7, 14235-14238.

39. Giripunje, M. D., Fulke, A. B. and Meshram, P. U., Effect of idol immersion on water quality and tilapia fish in Futala, Gandhisagar and Ambazari lakes of Nagpur, India. Springerplus, 2014, 3(1), 669.

40. Vyas, A., Bajpai, A., Verma, N. and Dixit, S., Heavy metal contamination cause of idol immersion activities in urban lake Bhopal, India. J. Appl. Sci. Environ. Manage., 2007, 11(4), 37-39.

41. D’Adamo, R., Specchiulli, A., Cassin, D., Botter, M., Zonta, R. and Fabbrocini, A., The effect of floods on sediment contamination in a microtidal coastal lagoon: the Lagoon of Lesina, Italy. Arch. Environ. Contam. Toxicol., 2014, 67(3), 297-309.

42. Solaraj, G., Dhanakumar, S., 'Mohanraj, R. and Rutharvel Murthy, $\mathrm{K}$., Water quality in select regions of Cauvery Delta River basin, southern India, with emphasis on monsoonal variation. Environ. Monit. Assess., 2010, 166, 435-444.

ACKNOWLEDGEMENTS. We thank the authorities of Bharathidasan University, Tiruchirappalli, for providing the necessary facilities to carry out this study, and the Ministry of Earth Science, Government of India (Ref. No.: MoES/36/OOIS/Extra./9/2013) for providing AAS facilities. We also thank Mr P. Vignesh and Mr K. Sridhar (Bharathidasan University) for help in preparing the map of the study area.

Received 21 September 2019; revised accepted 29 September 2020

doi: $10.18520 / \mathrm{cs} / \mathrm{v} 120 / \mathrm{i} 1 / 200-208$ 